\title{
Yield and Chemical Composition of Chinese Cabbage in Relation to Thermal Regime as Influenced by Row Covers
}

\author{
Diego A. Moreno ${ }^{\mathbf{1}}$ and Gemma Víllora \\ Departamento de Biología Vegetal, Facultad de Ciencias, Universidad de Granada, Fuentenueva S/N, \\ E-18071, Granada, Spain
}

Joaquín Hernández

Departamento de Producción Vegetal, E.P.S. Universidad de Almería, Ctra. Sacramento s/n, La Cañada de San Urbano, 04120, Almería, Spain

Nicholas Castilla
Departamento de Horticultura, C.I.F.A. Camino de Purchil S/N, 2027-18004 Granada, Spain

Luis Romero Monreal ${ }^{1}$

Departamento de Biología Vegetal, Facultad de Ciencias, Universidad de Granada, Fuentenueva S/N, E-18071, Granada, Spain

\begin{abstract}
AdDITIONAL INDEX WORDS. Brassica rapa, floating row covers, organic acids, nonstructural carbohydrates, cell wall composition
Abstract. During three consecutive years of field experiments, three crop-covering treatments [noncovered (C), perforated polyethylene (PO, 500 holes $\left./ \mathrm{m}^{2}\right)$, and a nonwoven polypropylene (AO) sheet] were used to create different environmental conditions for growth of 'Nagaoka 50' chinese cabbage [Brassica rapa L. (Pekinensis Group)]. The PO and AO treatments reduced solar irradiance and increased air and root temperatures compared to $\mathrm{C}$ plants. Plants were sampled five times each year from transplanting to harvest, and fresh and dry weights, yield at harvest, leaf pH, citric and ascorbic acid concentrations, and cell-wall fractions were determined. The PO floating row cover was the most beneficial for yield and chemical composition of chinese cabbage of the early spring crop in southern Spain, where environmental conditions during an unfavorable season can injure sensitive crops.
\end{abstract}

Chinese cabbage [Brassica rapa (Pekinensis Group)], is a major leafy vegetable in east Asia because all the aboveground biomass is edible and highly nutritious, and is gaining worldwide market demand (Fu et al., 1993). However, in less suitable environments as in southern Spain, early spring field seeding may result in a high percentage of bolting. Thus, to produce a good spring crop, seedlings raised in the greenhouse and transplanted to the field may need to be protected with plastic row covers (Hernández et al., 1996; Wurr and Fellows, 1998). Use of floating row covers to protect plants against cool spring temperatures has increased substantially in commercial vegetable production systems (Lamont, 1996; Jenni et al., 1998). The benefits of plasticulture include more favorable temperature regimes, higher crop yields, and earlier, cleaner, and higher-quality produce (Andersen et al., 1999; Guttormsen, 1990). Nevertheless, little attention has been focused on chemical composition of plants grown under semiforcing conditions (Rosenfeld et al., 1998).

The sugar content of plants is extremely sensitive to changes in environmental conditions (Farrar and Gunn, 1996; Sasaki et al., 1996). Similarly, alterations in cell-wall composition occurred under different environmental conditions (Kubacka-

Received for publication 1 May 2001. Accepted for publication 17 Dec. 2001. The authors express gratitude to the Instituto Nacional de Investigación y Tecnología Agraria y Alimentaria (INIA) and the Dirección General de Investigación Agraria de la Consejería de Agricultura y Pesca de la Junta de Andalucía for financial support of this work within the framework of Research Projects INIA 8505 and INIA SC93-084 and to the C.I.F.A. for support of the experiments. The authors would like to thank David Nesbitt for reviewing, constructive comments, and for translation into English. Critical reviews of this manuscript by H. Chris Wien and Frank A. Blazich are gratefully acknowledged.

${ }^{1}$ Corresponding authors; e-mail lromero@ugr.es.
Zebalska and Kacperska, 1999). Firmness appeared to be governed by the cell-wall polysaccharide content and it can be used to describe the texture in citrus (Citrus L. sp.) (Muramatsu et al., 1999), winter squash (Cucurbita maxima Duchesne ex Lam) (Wakabayashi et al., 1999), and chinese cabbage (Fuchigami et al., 1995, 1998). Thus, in the present investigation biomass and chemical composition of chinese cabbage transplanted in early spring in relation to season-extending techniques (floating row covers) were examined.

\section{Materials and Methods}

EXPERIMENTAL DESIGN AND GROWING CONDITIONS. The experimental site, located in Granada, southern Spain (lat. $37^{\circ} 10^{\prime} 11^{\prime} \mathrm{N}$; long. $\left.3^{\circ} 38^{\prime} 10^{\prime} \mathrm{W}\right), 600 \mathrm{~m}$ above sea level, has a Mediterranean climate, with average annual precipitation of $\approx 400 \mathrm{~mm}$. The experiments were conducted in 1994, 1995, and 1996. Seeds of 'Nagaoka 50' chinese cabbage, were sown in black polyethylene trays (8 Feb. 1994, 10 Feb. 1995, and 8 Feb. 1996) containing a medium of 4 compost (plant debris) : 1 vermiculite (by volume) and kept under controlled greenhouse conditions $\left(24 \pm 5^{\circ} \mathrm{C}, 60 \%\right.$ to $80 \%$ relative humidity (RH), and a 14 -h photoperiod of 300 $\mu \mathrm{m} \cdot \mathrm{m}^{-2} \cdot \mathrm{s}^{-1}$ photosynthethic active radiation $(P A R)$. At the fourleaf stage, with fresh weight (FW) exceeding $2 \mathrm{~g}$, the seedlings were transplanted to the field. The soil of the plots, sampled before planting, showed the following characteristics: Xerofluvent or calcareous Fluvisol; $45.3 \%$ sand, $43.2 \%$ silt, and $11.2 \%$ clay; $\mathrm{pH}$ (1 soil: 2.5 water) 8.6 ; electrical conductivity (EC) $1.1 \mathrm{dS} \cdot \mathrm{m}^{-1}$; total $\mathrm{N} 0.1 \% ; \mathrm{CaCO}_{3} 11.2 \%$; extractable $\mathrm{P}\left(58 \mu \mathrm{g} \cdot \mathrm{g}^{-1}\right)$ and $\mathrm{K}(115$ $\left.\mu \mathrm{g} \cdot \mathrm{g}^{-1}\right)$, cation-exchange capacity $\left(7.5 \mathrm{cmol}(+) \mathrm{kg}^{-1}\right)$. The charac- 
teristics of the irrigation water were: $\mathrm{pH} 7.65 ; \mathrm{EC} 1.05 \mathrm{dS} \cdot \mathrm{m}^{-1} ; \mathrm{Cl}^{-}$ $58.5 \mathrm{mg} \cdot \mathrm{L}^{-1} ; \mathrm{Na}^{+} 25 \mathrm{mg} \cdot \mathrm{L}^{-1}$; and $\mathrm{HCO}_{3}{ }^{-} 369 \mathrm{mg} \cdot \mathrm{L}^{-1}$. The plants were flood irrigated at transplanting to aid establishment and then weekly during growth.

At seeding, the fungicide zinc ethylenebis-dithiocarbamate (Zineb, Agrofit Soc. Coop., Valencia, Spain) was used at $2 \mathrm{~g} \cdot \mathrm{m}^{-2}$, and at transplanting $\gamma-1,2,3,4,5,6$-hexachloro-cyclohexane (Lindane, Agrindustrial S.A., Barcelona, Spain) was used at $4 \mathrm{~g} \cdot \mathrm{m}^{-2}$. After the plastic covers were removed, a solution of $\mathrm{CaCl}_{2}$ at 0.3 $\mathrm{g} \cdot \mathrm{L}^{-1}$ was applied to the foliage to prevent tipburn.

Each plot was oriented east-west and measured $4 \times 1.5 \mathrm{~m}$, with four rows of 12 plants each, plants being spaced $\approx 0.3 \times 0.3 \mathrm{~m}$ (11 plants $\left./ \mathrm{m}^{2}\right)$. For the laboratory analyses, only plants from the central rows were used.

The experiment was a randomized complete block design with four replications and three row covering treatments: noncovered control plants $(\mathrm{C})$, perforated polyethylene (PO, $50 \mu \mathrm{m}$ thick and 500 holes $/ \mathrm{m}^{2}$, each $10 \mathrm{~mm}$ in diameter), and a nonwoven polypropylene sheet (AO) (Agryl P17; Sodoca Fiberweb, Biesheim, France). Floating row covers (PO and $\mathrm{AO}$ ) were applied by cutting a piece of netting larger than the area to be covered which were laid out over the beds, leaving some slack for growth. The edges were secured by placing soil on the cloth, completely covering the edges. Then, the covers were anchored with rocks or other weights. Plots were covered on the day of transplanting (35-d-old plants $=35$ DOP $)$ and covers were kept on as long as possible to produce environmental differences between treatments. They were removed permanently when they began to interfere with further plant growth (80 DOP). Fifteen days after the covers were removed, final data were recorded (95 DOP).

A portable agrometeorological station was installed in the test plots to record, both in the open air and under the row covers, the following parameters: soil temperature at 5 and $15 \mathrm{~cm}$ depths, air temperature (at plant height), $\mathrm{RH}$, and solar radiation. The station consisted of a CR-21X datalogger (Campbell Scientific Co., Logan, Utah) programmed to record measurements every $15 \mathrm{~min}$ and average these each hour, for all the sensors except solar radiation sensors, from which data were recorded every minute. The temperature sensors used both in the open and under the covers were 107 Temperature Probes (Campbell Scientific Co.), with a maximum error of $\pm 0.4^{\circ} \mathrm{C}$ within the range of $-23{ }^{\circ} \mathrm{C}$ to $48^{\circ} \mathrm{C}$. Pyranometers (LI-200SA; LI-COR Inc., Lincoln, Nebr.) determined solar radiation in the open air and under the covers. The sensors used for measuring $\mathrm{RH}$ were of two types: ventilated aspirator psychrometers (wet bulb - dry bulb), and MP 100 sensors (Rotronic Instrument Corp., Huntington, N.Y.) to measure moisture in the solid state. The mean values recorded for environmental conditions during the three growing seasons are listed in Table 1 .

The fertilizer program was the same as that used by local farmers. A complete granular soluble fertilizer supplying N, P, and $\mathrm{K}$ at 200 , 100 , and $350 \mathrm{~kg} \cdot \mathrm{ha}^{-1}$, respectively, was mixed into the soil before planting. Subsequently, ammonium nitrosulphate $(26 \% \mathrm{~N})$ and $\mathrm{KNO}_{3}(13 \% \mathrm{~N}, 45 \% \mathrm{~K})$ was supplied in two applications throughout plant growth totaling 170 and $360 \mathrm{~kg} \cdot \mathrm{ha}^{-1}$ ammonium nitrosulphate and $\mathrm{KNO}_{3}$, respectively.

Plant SAmpling AND analyses. Plants were sampled at 15-d intervals throughout the growing period (five samplings) and samples of four plants (whole tops) were removed from each plot. For sampling, the row covers were removed for a maximum of half an hour at a time. The plants were severed at the soil surface and fresh weights (FWs) recorded. At harvest (95 DOP), 10 plants were sampled for total yield of all experimental plots. Afterwards the external leaves were removed to prepare marketable heads. These were weighed and then the malformed heads, those with any defects, and those weighing $<500 \mathrm{~g}$ were discarded. Plant samples were reweighed after oven drying at $70{ }^{\circ} \mathrm{C}$ for $24 \mathrm{~h}$.

LEAF PH AND CITRIC ACID CONCENTRATION. Fresh leaf samples without petioles $(5 \mathrm{~g})$ were added to $50 \mathrm{~mL}$ distilled water, and, after homogenization, were filtered through cheesecloth. The $\mathrm{pH}$ was determined on the remaining filtrate with a digital $\mathrm{pH}$ meter(CRISON 507, Crison Instruments S.A., Barcelona, Spain) and $30 \mathrm{~mL}$ of filtrate were titrated to $\mathrm{pH} 8.2$ with $0.1 \mathrm{~N} \mathrm{NaOH}$ to determine citric acid concentration (Víllora et al., 1999).

LEAF ASCORBIC ACID CONCENTRATION. Five grams FW of leaf tissue was ground with $50 \mathrm{~mL}$ of $0.4 \%$ oxalic acid in a chilled mortar. The extract was filtered and centrifuged for $10 \mathrm{~min}$ at $5000 \mathrm{~g}_{\mathrm{n}}$ and $4{ }^{\circ} \mathrm{C}$. The supernatant was used for ascorbic acid determination, based on the reaction of 2,6-dichloroindophenol and ascorbic acid (Schonhof and Krumbein, 1996).

NonSTRUCTURAL CARbohydrate CONCENTRATIONS. Samples of dry leaf tissue $(1.0 \mathrm{~g})$, homogenized in $5 \mathrm{~mL} 90 \%$ ethyl alcohol and $10 \mathrm{~mL} \mathrm{70 \%} \mathrm{ethyl} \mathrm{alcohol,} \mathrm{were} \mathrm{filtered} \mathrm{and} \mathrm{centrifuged} \mathrm{at} 1500 \mathrm{~g}_{\mathrm{n}}$ for $10 \mathrm{~min}$ (Víllora et al., 1999). Glucose, fructose, and sucrose concentrations were determined in the supernatant by spectrophotometry at $650 \mathrm{~nm}$, using the colorimetric assay with anthrone reagent (Irigoyen et al., 1992). Starch was determined from the dried residue of the previous extraction, which was incubated in $4 \mathrm{M}$ sodium-acetate buffer ( $\mathrm{pH} 4.5), 0.5 \% \mathrm{w} / \mathrm{w} \alpha$-glucoamylase, and distilled water for $48 \mathrm{~h}$ at $37^{\circ} \mathrm{C}$. After determination of glucose in the supernatant, starch values were expressed by multiplication by 0.9 of the glucose concentration obtained (Ettel, 1981).

Cell-wall Fractionation. Cell-wall fractions were extracted using the protocol of Wakabayashi et al. (1999) and reported in Muramatsu et al. (1999). Samples were homogenized with a 5-fold volume of $100 \%$ methanol and centrifuged at $1000 \mathrm{~g}_{\mathrm{n}}$ for $10 \mathrm{~min}$. The supernatant was discarded, then $80 \%$ ethyl-alcohol was added to the pellet, and the samples were boiled for $10 \mathrm{~min}$ followed by centrifugation at $1000 g_{\mathrm{n}}$ for $10 \mathrm{~min}$. The residue was washed three times with $100 \%$ acetone and then with 1 methanol : 1 chloroform (by volume). The washed residue was dried at $40{ }^{\circ} \mathrm{C}$. The water fraction was extracted with deionized water for $10 \mathrm{~min}$ at $95^{\circ} \mathrm{C}$. The residue was washed twice with distilled water, and after repeated extraction and centrifugation at $1000 g_{\mathrm{n}}$ for $10 \mathrm{~min}$, the supernatant was added to the water fraction. The washed residue was then treated with 2 units porcine pancreatic $\alpha$-amylase (type I-A, Sigma, St. Louis)/mL in $100 \mathrm{~mm}$ sodium-acetate buffer ( $\mathrm{pH}$ 6.5) for $2 \mathrm{~h}$ at 37 ${ }^{\circ} \mathrm{C}$, then washed again with deionized water. The ethylenediaminetetraacetic acid (EDTA) fraction was extracted three times by treatment with $50 \mathrm{~mm}$ EDTA in 50 mm sodium-phosphate buffer (pH 6.8) for $15 \mathrm{~min}$ at $95^{\circ} \mathrm{C}$. Hemicellulose was extracted with $17.5 \%(\mathrm{w} / \mathrm{v}) \mathrm{NaOH}$, containing $0.02 \% \mathrm{NaBH}_{4}$, for $18 \mathrm{~h}$. Again, the residue was washed with $4 \%$ acetic acid, and after acetone was added, dried overnight at $40{ }^{\circ} \mathrm{C}$. The residue was dissolved in $72 \%$ $\mathrm{H}_{2} \mathrm{SO}_{4}$. One hour later, distilled water was added, and after separation through a glass filter, the solvent was regarded as the cellulose fraction. The sugar concentration in each fraction was measured by the phenol-sulfuric acid method (Dubois et al., 1956), using a glucose standard, and uronic acid was determined by the calvazol method (Galambos, 1967), using a galacturonic acid standard.

Statistical ANALYSIS. Data were subjected to analysis of variance (ANOVA) procedures and means were separated using Duncan's multiple range test $(P<0.05)$. Simple regression analyses were also used, together with correlations between parameters.

Results of the parameters measured, varied slightly between 
Table 1. Means $(n=3320)$ of environmental parameters recorded during the three growing seasons of 'Nagaoka 50' chinese cabbage, grown in the open (noncovered) $(\mathrm{C})$, under perforated polyethylene $(\mathrm{PO})$, or polypropylene $(\mathrm{AO})$ floating row covers.

\begin{tabular}{lcccr}
\hline $\begin{array}{l}\text { Covering } \\
\text { treatment }\end{array}$ & $\begin{array}{c}\text { Aerial } \\
\text { temp } \\
\left({ }^{\circ} \mathrm{C}\right)\end{array}$ & $\begin{array}{c}\text { Root-zone } \\
\text { temp }\left({ }^{\circ} \mathrm{C}\right) \\
(5 \mathrm{~cm} \mathrm{depth})\end{array}$ & $\begin{array}{c}\text { Relative } \\
\text { humidity } \\
(\%)\end{array}$ & $\begin{array}{c}\text { Solar } \\
\text { radiation } \\
\left(\mathrm{W} \cdot \mathrm{m}^{-2}\right)\end{array}$ \\
\hline $\mathrm{C}$ & $14.1 \mathrm{c}^{\mathrm{z}}$ & $18.8 \mathrm{~b}$ & $57.5 \mathrm{~b}$ & $\begin{array}{c}\text { Radiant } \\
\text { exposure } \\
\left(\mathrm{kJ} \cdot \mathrm{m}^{-2}\right)\end{array}$ \\
PO & $21.4 \mathrm{a}$ & $24.0 \mathrm{a}$ & $61.9 \mathrm{a}$ & $31,334 \mathrm{a}$ \\
$\mathrm{AO}$ & $19.1 \mathrm{~b}$ & $23.8 \mathrm{a}$ & $63.4 \mathrm{a}$ & $207.2 \mathrm{~b}$ \\
ANOVA & $P<0.001$ & $P<0.001$ & $P<0.01$ & $205.2 \mathrm{~b}$ \\
\hline
\end{tabular}

${ }^{\mathrm{z}}$ Mean separation within columns by Duncan's multiple range test, $P<0.05$.

years, and homogeneity of variance was tested by accepted methods (Bender et al., 1989; González and Ollero, 1997) and found to be nonsignificant. Therefore, statistical analyses of the data from each year were pooled to avoid duplication of the calculations and to simplify presentation of results.

\section{Results and Discussion}

Air temperatures recorded over the three experimental years were the highest for the PO treatment, while in the AO, the values were intermediate between $\mathrm{PO}$ and $\mathrm{C}$ (Table 1). Such increases have been noted by many investigators (e.g., Lamont, 1996; Wurr and Fellows, 1998) and may have resulted from the modified thermal regime conditions under the covers as well as permeability of the covers (Hemphill and Crabtree, 1988; Montsenbocker and Bonanno, 1989). Soil temperatures at a 5-cm depth were higher in $\mathrm{PO}$ and $\mathrm{AO}$ than in $\mathrm{C}$, by an average of $5^{\circ} \mathrm{C}$ (Table 1). However, the soil temperature did not usually rise as much as the air temperature, due to the thermal inertia of the soil (Guttormsen, 1990). RH values under the covers (PO and $\mathrm{AO}$ ) were $8 \%$ and $10 \%$ higher, respectively, than in $\mathrm{C}$, due to reduced evapotranspiration in the protected zone which produced a mini-greenhouse effect (Choukr-Allah et al., 1994; Gimenez et al., 2001; Lamont, 1996). Permeability of AO, an agrotextyle without perforations, favored slightly higher humidity than under the PO cover, although the sightly higher values in the AO may have been due simply to condensation of water in the field conditions (Guttormsen, 1990; Motsenbocker and Bonanno, 1989). As expected, $\mathrm{PO}$ and $\mathrm{AO}$ reduced partly the sunlight reaching the plants (Healey and Rickert, 1998), reducing instantaneous solar radiation by $13 \%$ and lowering cumulative solar radiation during the entire cycle by $17 \%$ and $16 \%$, respectively. Therefore, the row covers imposed a constraint to crop growth under these conditions. However, in the crop season and in latitudes similar to ours, the reduced irradiance under the covers might have been compensated by the greater leaf area index of these plants, the increased air and soil temperature under the covers, and by improved light distribution within the protected canopy, allowing crop growth and development (Gimenez et al., 2001; Hernández et al., 1996; Jenni et al., 1998).

The influence of the thermal regime on $\mathrm{FW}$ production per plant (Table 2) was most notable in PO, the treatment that reached the highest values, surpassing $\mathrm{C}$ by $123 \%$, while $\mathrm{AO}$ surpassed $\mathrm{C}$ by $105 \%$. Similarly, DW of the shoot (Table 2) was highest under PO, exceeding $\mathrm{C}$ values by $34 \%$, while $\mathrm{AO}$ was $18 \%$ higher than $\mathrm{C}$. The accelerated growth was probably the result of greater foliar expansion, which provides better distribution of mineral nutrients as

Table 2. Biomass components and marketable and total yields of 'Nagaoka 50' chinese cabbage grown in the open (noncovered) (C), under perforated polyethylene (PO), or polypropylene (AO) floating row covers. ${ }^{\mathrm{z}}$

\begin{tabular}{|c|c|c|c|c|}
\hline \multirow{2}{*}{$\begin{array}{l}\text { Covering } \\
\text { treatment }\end{array}$} & \multirow{2}{*}{$\begin{array}{l}\text { Fresh wt } \\
\text { (g/plant) }\end{array}$} & \multirow{2}{*}{$\begin{array}{l}\text { Dry wt } \\
\text { (g/plant) }\end{array}$} & \multicolumn{2}{|c|}{ Yield $\left(\mathrm{t} \cdot \mathrm{ha}^{-1}\right)$} \\
\hline & & & Marketable $^{\mathrm{y}}$ & Total $^{\mathrm{x}}$ \\
\hline $\mathrm{C}$ & $236.2 c^{w}$ & $11.8 \mathrm{c}$ & $12.8 \mathrm{c}$ & $58.2 \mathrm{c}$ \\
\hline $\mathrm{AO}$ & $484.9 \mathrm{~b}$ & $14.0 \mathrm{~b}$ & $74.0 \mathrm{~b}$ & $120.9 \mathrm{~b}$ \\
\hline ANOVA & $P<0.05$ & $P<0.05$ & $P<0.001$ & $P<0.001$ \\
\hline
\end{tabular}

${ }^{\mathrm{z}}$ All data represent the means of five samplings for 3 years of field experiments.

yThe external leaves were removed to prepare the marketable produce (marketable heads).

${ }^{x}$ Ten plants were severed (the roots were cut off) at the soil surface and each plant (whole tops) was weighed fresh from all experimental plots.

${ }^{\text {w}}$ Mean separation within columns by Duncan's multiple range test, $P<0.05$.

Table 3. Leaf pH, citric acid and ascorbic acid, and leaf nonstructural carbohydrate concentrations of 'Nagaoka 50' chinese cabbage, grown in the open (uncovered) (C), under perforated polyethylene (PO), or polypropylene (AO) floating row covers. ${ }^{\mathrm{z}}$

\begin{tabular}{|c|c|c|c|c|c|c|c|}
\hline \multirow{2}{*}{$\begin{array}{l}\text { Covering } \\
\text { treatment }\end{array}$} & \multirow[b]{2}{*}{$\mathrm{pH}$} & \multirow{2}{*}{$\begin{array}{c}\text { Citric } \\
\text { acid } \\
(\mathrm{mg} / 100 \mathrm{~g} \mathrm{FW})\end{array}$} & \multirow{2}{*}{$\begin{array}{c}\text { Ascorbic } \\
\text { acid } \\
\left(\mathrm{mg} \cdot \mathrm{g}^{-1} \mathrm{FW}\right)\end{array}$} & \multicolumn{4}{|c|}{$\begin{array}{l}\text { Carbohydate concn } \\
\left(\mathrm{mg} \cdot \mathrm{g}^{-1} \mathrm{DW}\right)\end{array}$} \\
\hline & & & & Glucose & Fructose & Sucrose & Starch \\
\hline$\overline{\mathrm{C}}$ & $6.29 \mathrm{~b}^{\mathrm{y}}$ & $0.15 \mathrm{a}$ & $0.59 \mathrm{~b}$ & $11.1 \mathrm{a}$ & $11.6 \mathrm{a}$ & $10.9 \mathrm{a}$ & $55.6 \mathrm{a}$ \\
\hline PO & $6.41 \mathrm{a}$ & $0.11 \mathrm{~b}$ & $0.65 \mathrm{a}$ & $9.8 \mathrm{ab}$ & $10.0 \mathrm{ab}$ & $9.4 \mathrm{ab}$ & $53.9 \mathrm{a}$ \\
\hline $\mathrm{AO}$ & $6.36 \mathrm{ab}$ & $0.11 \mathrm{~b}$ & $0.63 \mathrm{a}$ & $9.3 \mathrm{~b}$ & $9.4 \mathrm{~b}$ & $8.9 \mathrm{~b}$ & $53.7 \mathrm{a}$ \\
\hline ANOVA & $P<0.05$ & $P<0.001$ & $P<0.05$ & $P<0.05$ & $P<0.05$ & $P<0.05$ & $P<0.10$ \\
\hline
\end{tabular}

${ }^{\mathrm{z}}$ All data represent means of five samplings for 3 years of field experiments.

yMean separation within columns by Duncan's multiple range test, $P<0.05$. 


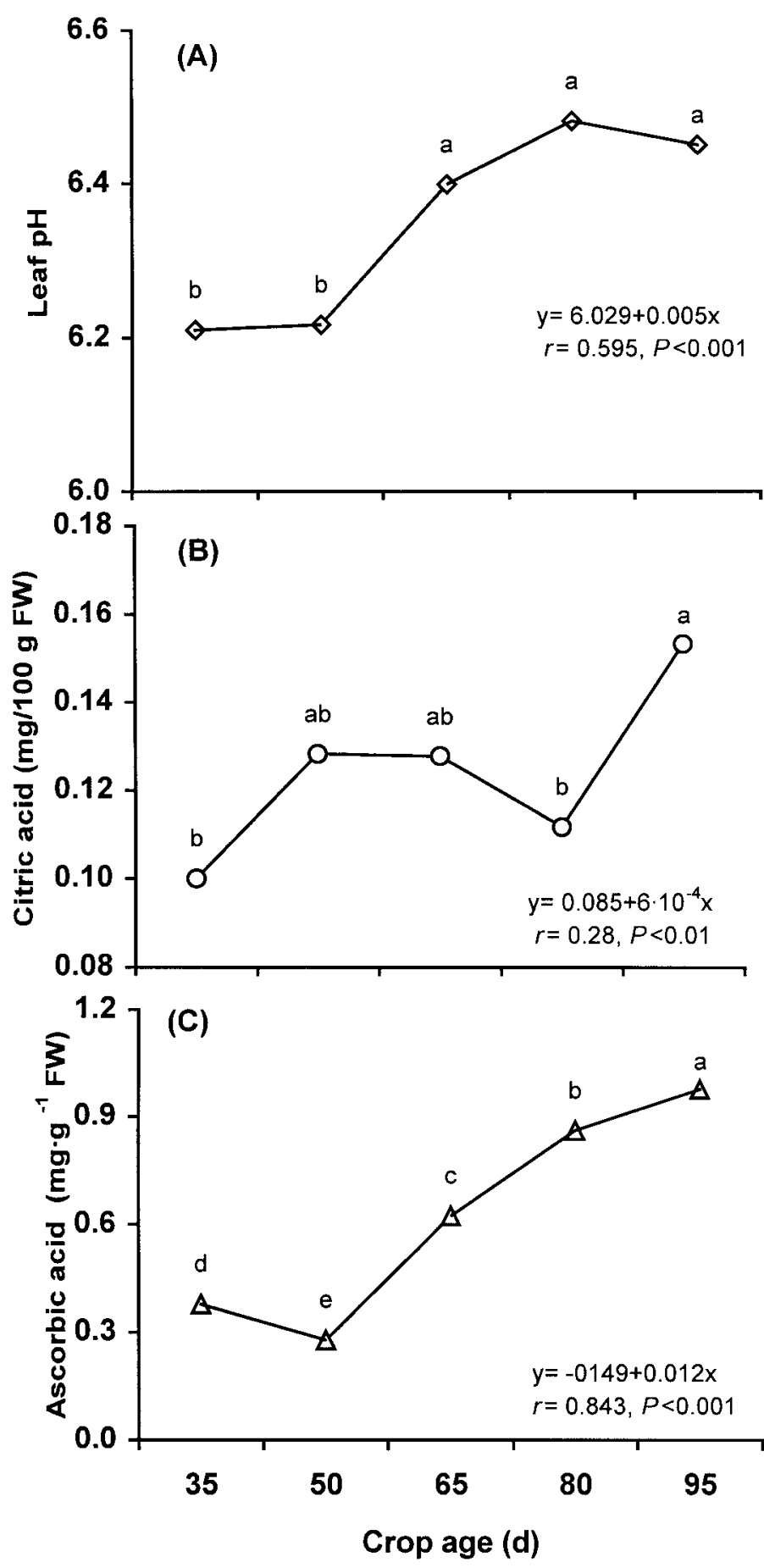

Fig.1. Changes in leaf (A) $\mathrm{pH},(\mathbf{B})$ citric acid, and (C) ascorbic acid during development of 'Nagaoka 50' chinese cabbage. All data represent the means of four replications at every sampling and treatment for 3 years of field experiments. Means within a series followed by the same letter are not significantly different by Duncan's multiple range test, $P<0.05)$.

well as photoassimilates in the shoot (Fu et al., 1993; Kleier et al., 1998). We found that FW as well as DW increased $(P<0.001$, data not presented) with plant age. Between the third and fourth sampling (65 to 80 DOP), both fresh and DWs represented half of the total biomass recorded at the end of the crop cycle (mean values at 95 DOP: $934.4 \mathrm{~g} \mathrm{FW} /$ plant and $34.3 \mathrm{~g}$ DW/plant).

Marketable yield was highest in PO, being 524\% higher than in $\mathrm{C}$, and the AO treatment was $486 \%$ higher (Table 2). The lowest total yield was given by $\mathrm{C}$, while $\mathrm{PO}$ gave the highest total yield, $111 \%$ higher than $\mathrm{C}$, and AO $108 \%$ higher (Table 2). Increased yield was proportional to the greater biomass under covers, as other researchers have also found (Lamont, 1996; Wurr and Fellows, 1998). Plants of the $C$ treatment had less weight per plant than those grown under cover. This led to significantly lower yield also caused by a higher rate of bolting $(33.5 \%)$ than under the covers $(5.2 \%$ under $\mathrm{PO} ; 6.9 \%$ under $\mathrm{AO})$, another consequence of temperature differences (Guttormsen, 1990; Hernández et al., 1996).

For a summary economic analysis, we calculated the increases in costs of the crop and in yield caused by the use of floating row covers, bearing in mind that no specialized equipment was necessary to place or remove the covers. Use of $\mathrm{PO}$ and $\mathrm{AO}$ made the crop profitable, grossing some $325 \%$ more than open field cultivation (C), which under the growing conditions in the study zone were unprofitable (Hernández et al., 1996).

As sensory quality parameters, leaf $\mathrm{pH}$ was lowest in the open crop (C) and highest in the PO treatment (Table 3). The highest citric acid concentration was found in $\mathrm{C}$, while $\mathrm{PO}$ and $\mathrm{AO}$ values were $27 \%$ lower. For ascorbic acid, $\mathrm{C}$ presented the lowest mean concentration, $\mathrm{PO}$ values being $10 \%$ higher and $\mathrm{AO}$ values $7 \%$ higher (without significant differences between these two treatments). Leaf $\mathrm{pH}$ increased during development $(P<0.001$; Fig. $1 \mathrm{~A})$, with the most pronounced increase between 50 and $65 \mathrm{~d}$. Citric acid concentration increased $153 \%(P<0.01)$ during development (Fig. 1B), while ascorbic acid concentration (Fig. 1C) increased $157 \%(P<0.001)$. The noncovered control plots (C), without reduced sunlight, registered the highest citric acid concentration as a result of higher phytosynthesis. These slightly but significantly higher citric acid concentrations could result in differences in taste (Rosenfeld et al., 1998). Citric acid can also aid in balancing the ionic content as an osmotic agent to balance the intracellular $\mathrm{pH}$ in osmoregulation processes in the uptake of mineral nutrients (Kim and Klieber, 1997) and was negatively correlated with leaf $\mathrm{pH}(r=-0.480, P<0.001)$. The ascorbic acid content was positively correlated to $\mathrm{FW}(r=0.708, P<0.001)$ and $\mathrm{pH}(r=0.427 ; P<0.001)$ and negatively correlated to the citric acid concentration $(r=0.293, P<0.01)$.

Change in foliar levels of sugars (nonstructural carbohydrates) is a sensitive indicator of the effects that different environmental conditions exert on photosynthesis (Farrar and Gunn, 1996). The glucose concentrations in $\mathrm{C}$ exceeded the levels found in $\mathrm{PO}$ $(13 \%)$ and $\mathrm{AO}(20 \%)$ (Table 3$)$. Fructose and sucrose concentrations also diminished in the following order: $\mathrm{C}>\mathrm{PO}>\mathrm{AO}$. Nevertheless, starch was not significantly affected by the treatments. Glucose, fructose, and sucrose concentrations increased $213 \%, 207 \%$, and $205 \%$, respectively, with plant development $(P$ $<0.001$; data not presented). However, starch concentration declined $33 \%(P<0.01$; data not presented $)$ in the last two samplings. The PO and AO covers reduced solar radiation, and consequently, in the open crop (C) greater photosynthesis and slower growth rate boosted sugar levels under our experimental field conditions (Sasaki et al., 1996).

The concentration of neutral sugars and uronic acids in the cell-wall fractions (Table 4) was found to be altered by the thermal regime, and it is notable that in the different fractions (hydrosoluble, pectic, hemicellulose, and cellulose fractions) the neutral sugar levels were higher than the uronic acids, decreasing in the order: $\mathrm{PO}>\mathrm{AO}>\mathrm{C}$. Concentrations of uronic acid in the pectic (EDTA fraction; Muramatsu et al., 1999) and hemicellulose fractions, on the other hand, were not affected by the 
Table 4. Sugar and uronic acid concentrations in cell wall fractions of 'Nagaoka 50' chinese cabbage, grown in the open (noncovered) (C), under perforated polyethylene (PO), or polypropylene (AO) floating row covers. ${ }^{\mathrm{Z}}$

\begin{tabular}{|c|c|c|c|c|}
\hline \multirow{2}{*}{$\begin{array}{l}\text { Covering } \\
\text { treatment }\end{array}$} & \multicolumn{4}{|c|}{ Cell-wall fraction } \\
\hline & Hydrosoluble & Pectic & Hemicellulose & Cellulose \\
\hline \multicolumn{5}{|c|}{ Neutral sugars $\left(\mathrm{mg} \cdot \mathrm{g}^{-1} \mathrm{DW}\right)$} \\
\hline $\mathrm{PO}$ & $4.7 \mathrm{a}$ & $6.2 \mathrm{a}$ & $2.8 \mathrm{a}$ & $6.0 \mathrm{a}$ \\
\hline $\mathrm{AO}$ & $4.1 \mathrm{~b}$ & $6.1 \mathrm{a}$ & $2.5 \mathrm{~b}$ & $5.9 \mathrm{a}$ \\
\hline ANOVA & $P<0.01$ & $P<0.001$ & $P<0.001$ & $P<0.01$ \\
\hline \multicolumn{5}{|c|}{ Uronic acids $\left(\mathrm{mg} \cdot \mathrm{g}^{-1} \mathrm{DW}\right)$} \\
\hline PO & $0.3 \mathrm{a}$ & $0.3 \mathrm{a}$ & $0.1 \mathrm{a}$ & $0.3 \mathrm{a}$ \\
\hline $\mathrm{AO}$ & $0.2 \mathrm{~b}$ & $0.3 \mathrm{a}$ & $0.1 \mathrm{a}$ & $0.2 \mathrm{~b}$ \\
\hline ANOVA & $P<0.05$ & $P<0.10$ & $P<0.10$ & $P<0.05$ \\
\hline
\end{tabular}

${ }^{\mathrm{z}}$ All data represent means of five samplings for 3 years of field experiments.

yMean separation within columns for neutral sugars or uronic acids by Duncan's multiple range test at $P<0.05$.

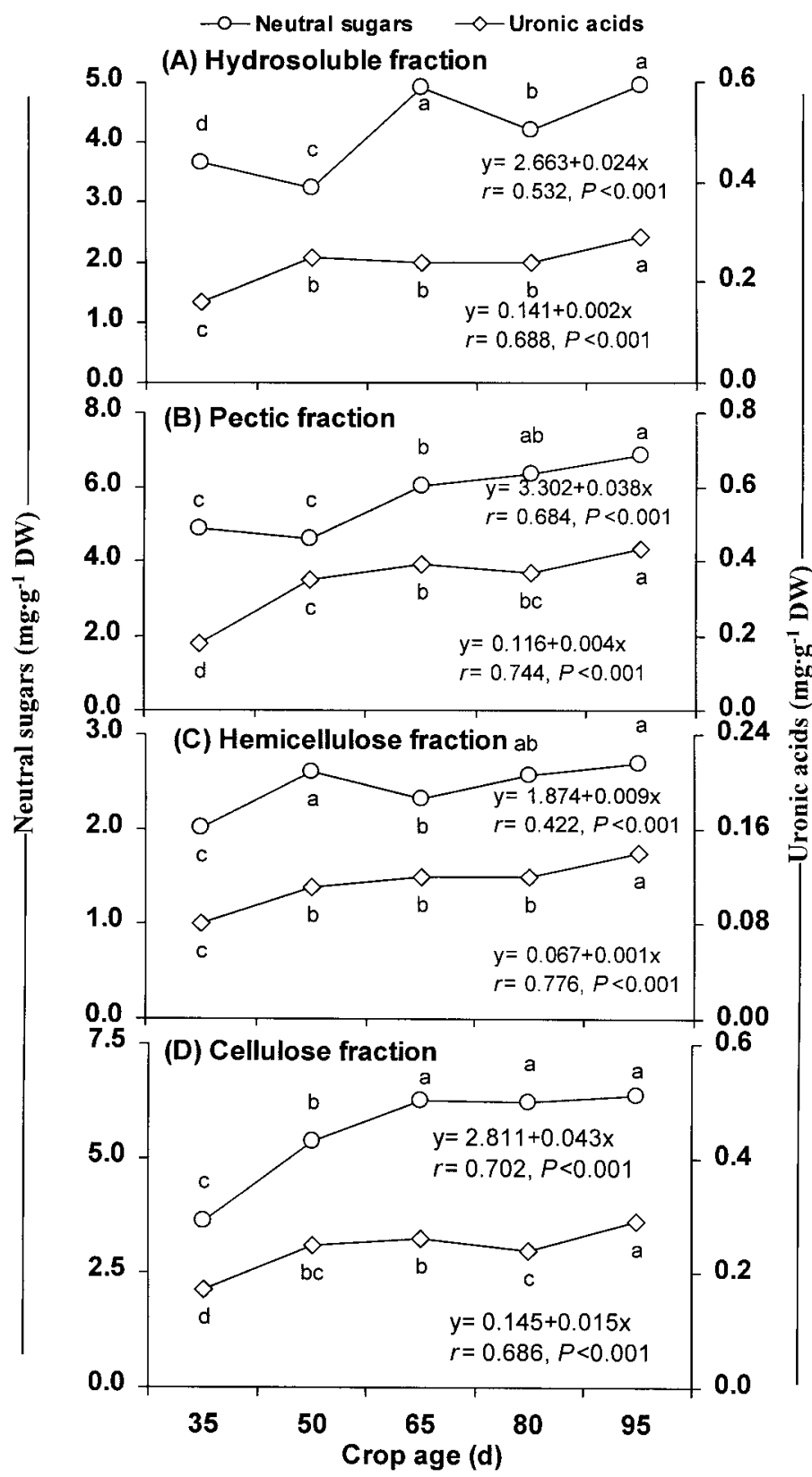

treatments. The relative concentration of neutral sugars and uronic acid was: pectic fraction $>$ cellulose fraction $>$ hydrosoluble fraction $>$ hemicellulose fraction (Table 4).

Leaf firmness can be determined by the relative amount of monosaccharides in cell-wall fractions, and a significant correlation was found by other researchers between firmness and cellwall composition (Fuchigami et al., 1995, 1998; Wakabayashi et al., 1999). In the present investigation, pectic and cellulose fractions showed higher monosacharide content (Table 4). Thus, it may be possible that alterations of the cell-wall fractions have implications for physical properties of the cell wall, this being an important component of plant responses to different temperature conditions (Kubacka-Zebalska and Kacperska, 1999; Muramatsu et al., 1999).

The temporal dynamic in all treatments of the neutral sugar and uronic acids in the different fractions of the cell walls (Fig. 2) showed increases $(P<0.001)$ related to plant age. The neutral sugar content in the hydrosoluble and pectic fractions (Fig. 2A and B) showed the lowest value at $50 \mathrm{~d}$ of age. The hemicellulose fraction (Fig. 2C) gave the highest value at $50 \mathrm{~d}$ of age. In the cellulose fraction (Fig. 2D), these values increased progressively over the entire cycle. The uronic acid content in the different fractions showed very similar changes (Fig. 2) with the most notable increase at the end of the cycle. Thus, changes during crop age in the hydrosoluble and pectic fractions could be associated with a high turnover rate to increase the composition of monosaccharides in the polysaccharide structures of the hemicellulose and cellulose fractions (Muramatsu et al., 1999; Wakabayashi et al., 1999).

In summary, the microclimatic conditions generated under the PO cover were most beneficial for chinese cabbage under the environmental conditions of early spring in southern Spain, where environmental conditions during an unfavorable season can injure sensitive crops. Use of this type of crop protection is advisable to enhance productivity and chemical composition of vegetables at low cost, but it would not be successful in environments (or seasons) of low irradiance.

Fig. 2. Changes during development in neutral sugars and uronic acid content in cell wall fractions of 'Nagaoka 50' chinese cabbage: (A) hydrosoluble fraction, (B) pectic fraction, (C) hemicellulose fraction, and (D) cellulose fraction. All data represent the means of four replications at every sampling and treatment for 3 years of field experiments. Means within a series followed by the same are not significantly different by Duncan's multiple range test, $P<0.05$. 


\section{Literature Cited}

Andersen, L., P., Brønnum, and M. Jensen. 1999. Influence of temporary covers on the growth of nursery tree seedlings. J. Hort. Sci. Biotechnol. 74:74-77.

Bender, F.E., L.W. Douglas, and A.Kramer. 1989. Statistical methods for food and agriculture. Food Products Press. New York.

Choukr-Allah, R., B. Hafidi, G. Reyd, and A. Hamdy. 1994. Influence of non-wovens on outdoor crops: Moroccan experience. Proc. XIII Intl. Congr. Plastics Assn. (CIPA) Meeting Plastics in Agriculture, Verona, Italy, 8-11 Mar.

Dubois M., K.A. Gilles, J.K. Hamilton, P.A. Rebers, and F. Smith. 1956. Colorimetric method for determination of sugars and related substances. Anal. Chem. 28:350-356.

Ettel, W. 1981. Eine neue enzymatische Stäerkebestimmung für Lebensmittel. Alimenta 20:7-11.

Farrar, J.F. and S. Gunn. 1996. Effects of temperature and atmospheric carbon dioxide on source-sink relations in the context of climate change, p. 389-406. In: E. Zamski and A.A. Schaffer (eds.). Photoassimilate distribution in plants and crops: Source-sink relationships. Marcel Dekker, New York.

Fu, I.-M., C. Shennan, and G.E. Welbaum. 1993. Evaluating chinese cabbage cultivars for high temperature tolerance, p. 570-573. In: J. Janick and J.E. Simon (eds.). New crops. Wiley, New York.

Fuchigami, M., K. Miyazaki, N. Hyakumoto, T. Nomura, and J. Sasaki. 1995. chinese cabbage midribs and leaves physical changes as related to freeze-processing. J. Food Sci. 60:1260-1264.

Fuchigami, M., N. Kato, and A. Teramoto. 1998. High-pressure-freezing effects on textural quality of chinese cabbage. J. Food Sci. 63:122-125.

Galambos, J.T. 1967. The reaction of carbazole with carbohydrate. I. Effect of borate and sulfate on the carbazole color of sugars. Anal. Biochem. 19:119-132.

Gimenez C., R.F. Otto, and N. Castilla. 2001. Productivity of leaf and root vegetable crops under direct cover. Scientia Hort. (in press.). Available at http://www.elsevier.com/locate/scihorti

González, A. and J. Ollero. 1997. Análisis Estadístico con Statgraphics. Colección Estadística Multivariable y Procesos Estocásticos. Grupo Editorial Universitario and Copias Plácido Cuadros S.L. (eds.). Granada, Spain.

Guttormsen, G. 1990. Effect of various types of floating plastic films on the temperatures and vegetable yield. Acta Hort. 267:37-44.

Healey, K.D. and K.G. Rickert. 1998. Shading material changes the proportion of diffuse radiation in transmitted radiation. Austral. J. Expt. Agr. 38:95-100.

Hemphill, D.D. and G.D. Crabtree. 1988. Growth response and weed control in slicing cucumbers under row covers. HortScience 113:4145.

Hernández, J., L. Romero, and N. Castilla. 1996. Análisis comparativo del crecimiento, p. 139-146. In:L. Romero(ed.). Valoración agronómica y análisis microclimático de la técnica de semiprotección de cubiertas flotantes sobre col china. Imp. Plácido Cuadros S.L., Granada, Spain. Irigoyen J.J., D.W. Emerich, and M. Sánchez-Diaz. 1992. Water stress induced changes in concentrations of proline and total soluble sugars in nodulated alfalfa (Medicago sativa) plants. Physiol. Plant. 84:5560.

Jenni, S., K.A. Stewart, D.C. Cloutier, and G. Bourgeois. 1998. Chilling injury and yield of muskmelon grown with plastic mulches, rowcovers, and thermal water tubes. HortScience 33:215-221.

Kim, B.S. and A. Klieber. 1997. Quality maintenance of minimally processed chinese cabbage with low temperature and citric acid dip. J. Sci. Food Agr. 75:31-36.

Kleier, C., B. Farnsworth, and W. Winner. 1998. Biomass, reproductive output, and physiological responses of rapid-cycling Brassica (Brassica rapa) to ozone and modified root temperature. New Phytol. 139:657-664.

Kubacka-Zebalska, M. and A. Kacperska. 1999. Low temperatureinduced modifications of cell wall content and polysaccharide composition in leaves of winter oilseed rape (Brassica napus L. var. oleifera L.). Plant Sci. 148:59-67.

Lamont, Jr., W.J. 1996. What are the components of a plasticulture vegetable system? HortTechnology 6:150-154.

Motsenbocker, C.E. and A.R. Bonanno. 1989. Row cover effects on air and soil temperatures and yield of muskmelon. HortScience 24:601603.

Muramatsu, N., T. Takahara, T. Ogata, and K. Kojima. 1999. Changes in rind firmness and cell wall polysaccharides during citrus fruit development and maturation. HortScience 34:79-81.

Rosenfeld, H.J., R.T. Samuelsen, and P. Lea. 1998. The effect of temperature on sensory quality, chemical composition and growth of carrots (Daucus carota L.). II. Constant diurnal temperatures under different seasonal light regimes. J. Hort. Sci. Biotechnol. 73:578-588.

Sasaki, H., K. Ichimura, and M. Oda. 1996. Changes in sugar content during cold acclimation and deacclimation of cabbage seedlings. Ann. Bot. 78:365-369.

Schonhof, I. and A. Krumbein. 1996. Content of essential substances of different broccoli types. Gartenbauwissenschaft 61S:281-288.

Víllora, G., D.A. Moreno, G. Pulgar, and L. Romero. 1999. Zucchini growth, yield, and fruit quality in response to sodium chloride stress. J. Plant Nutr. 22:855-861.

Wakabayashi, K., T. Hoson, and N. Sakurai. 1999. Auxin stimulates the synthesis but not the loosening of cell walls in isolated outer tissue of dark-grown squash (Cucurbita maxima Duch.) hypocotyls. J. Plant Physiol. 154:197-202.

Wurr, D.C.E. and J.R. Fellows. 1998. Leaf production and curd initiation of winter cauliflower in response to temperature. J. Hort. Sci. Biotechnol. 73:691-697. 